Abstracta Iranica Abstracta Iranica

Revue bibliographique pour le domaine irano-aryen

Volume 25 | 2004

Comptes rendus des publications de 2002

\title{
Women, Religion and Culture in Iran. Richmond, Curzon Press et Royal Asiatic Society, 2002, 231 p.
}

Azadeh Kian-Thiébaut

\section{(2) OpenEdition}

1 Journals

Édition électronique

URL : http://journals.openedition.org/abstractairanica/5099

DOI : $10.4000 /$ abstractairanica.5099

ISSN : 1961-960X

\section{Éditeur :}

CNRS (UMR 7528 Mondes iraniens et indiens), Éditions de l'IFRI

\section{Édition imprimée}

Date de publication : 15 mai 2004

ISSN : 0240-8910

\section{Référence électronique}

Azadeh Kian-Thiébaut, «Women, Religion and Culture in Iran. Richmond, Curzon Press et Royal Asiatic Society, 2002, 231 p. », Abstracta Iranica [En ligne], Volume 25 | 2004, document 300, mis en ligne le 15 mars 2006, consulté le 25 septembre 2020. URL : http://journals.openedition.org/abstractairanica/ 5099 ; DOI : https://doi.org/10.4000/abstractairanica.5099

Ce document a été généré automatiquement le 25 septembre 2020.

Tous droits réservés 


\title{
Women, Religion and Culture in Iran. Richmond, Curzon Press et Royal Asiatic Society, 2002, 231 p.
}

\author{
Azadeh Kian-Thiébaut
}

Cet ouvrage collectif est issu d'une conférence co-organisée par Sarah Ansari et Vanessa Martin à l'Université de Londres en 1998. Deux thèmes dominants, à savoir le rôle de la religion, en particulier du chi'isme dans la société iranienne et l'influence de l'État relient plusieurs des onze contributions réunies dans cet ouvrage. Depuis la fin de la dynastie des Qajars jusqu'à aujourd'hui les représentants de la religion et de l'État ont rivalisé pour imposer leurs visions de la société iranienne. Ces rivalités et ces luttes ayant pour enjeux la culture et l'identité iraniennes ont propulsé au cœur des débats les questions relatives aux femmes.

\section{INDEX}

Thèmes : 12.1. Iran

nompropre Qâjârs

\section{AUTEURS}

AZADEH KIAN-THIÉBAUT

CNRS - Paris 